ISSN 2414-1143

Научный альманах стран Причерноморья. 2018. Том 15. № 3

DOI 10.23947/2414-1143-2018-15-3-11-17

UDC 1:316+008

\title{
SOCIO-CULTURAL FACTORS OF DEVELOPMENT OF NATIONAL PHILOSOPHY
}

\author{
(C) Vachit Kh. Akaev \\ Grosny State Oil Technical University by Academician M.D. Millionschikov \\ Grozny, Chechen region, Russian Federation \\ science-almanac@mail.ru
}

In the article, national philosophy is viewed as the result of a long historical development of the national culture, realized through various forms of activity, including mental, reflexive features of the ethnos, as well as its individual members. Having a character of continuity, it comprehends the cultural originality, intellectual activity of individuals belonging to a particular ethnic group or nation. Certainly, national philosophy, comprehends universal values, has its own specific features that are manifested in different peoples in the course of analysis of the life of a person, people, societies. In the context of modernity, representatives of national philosophy make attempts to comprehend classical and non-classical theories, giving it a special form and content. The national philosophy is also specific for the peoples of the North Caucasus, who have unique ethnographic, spiritual values, and unique cultural achievements.

Key words: national spirit, national culture, reflection, national philosophy, empiricism, neo-positivism, analytical philosophy, postmodernism.

\section{[B.Ч. Акаев Социокультурные факторы развития национальной философии]}

В работе анализируется результат длительного исторического развития национальной философии, культуры, реализуемые посредством различных форм деятельности, в том числе ментальных, рефлексивных особенностей этноса, а также отдельного его представителя. Бу-дучи преемственной, философия научно обосновывает культурное своеобразие, интеллекту-альную деятельность отдельных личностей, принадлежащих к тому или иному этносу, нации. Раскрывается научная концепция национальной философии, осмысляющей общечеловеческие ценности, имеющей специфические черты, которые проявляются у разных народов в ходе анализа их совместной жизни, деятельности людей, социальных групп. В контексте современности подчеркнута важность для исследования фундаментальных трудов в области национальной философии, в которых предпринимаются попытки осмыслить классические и неклассические теории, придавая ей особую форму и содержание. Обосновывается специфичность национальной философии у различных народов Северного Кавказа, обладающих уникальными этнографическими, духовными ценностями, своеобразными культурными достижениями.

Ключевые слова: народный дух, национальная культура, социальные факторы, реф-лексия, национальная филлософия, эмпиризм, неопозитивизм, аналитическая философия, по-стмодернизм.

Vachit Kh. Akaev - PhD of philosophy, professor. Grosny State Oil Technical University by Academician M.D. Millionschikov. Grozny, Chechen region, Russian Federation.

Акаев Вахит Хумидович - доктор фрилософрских наук, професссор. Грозненский государственный нефртяной технический университет им. академика М.Д. Миллионщикова. г. Грозный, Чеченская Республика, Россия.

The formation of a national philosophy of an ethnos is a complex historical phenomenon, accompanied with social and cultural dynamics, during which the national character manifests itself and unique components of rich experience, features of ethnic mentality, worldview and world outlook are realized. Over time, the intellectual development of the people, their general spiritual state, cultural achievements become the subject of purpose- 
ful reflection, philosophical understanding of life, the complex life of an ethnos. The intellectual activity carried out within the framework of the national culture produces philosophical ideas, theories reflecting social relations, and features of the people's world view.

Culture, from the point of view of Hegel, is a manifestation of the national spirit, which denotes cultural and historical projections of the absolute spirit. The movement of history, the sociocultural dynamics of an ethnos is the confrontation of national spirits with each other, and the empirical expression of the national spirit is the people with its social and cultural achievements. The national spirit through the national character influences the formation of the individual spirit. He is aware of himself in religion, art, law, politics, philosophy of this or that nation. A state is an organization of a certain people, an objectified expression of the specifics of the national spirit. From the point of view of the Hegelian position, only in philosophy the national spirit finally reveals and captures its essence.

The spirit of the nation ensures the integrity of the national culture, but it does not remain unchanged, existing independently of the activities of people. National culture, being in interaction with the world, borrowing scientific, technical inventions, social projects, acquires a dynamic nature. Conflicting tendencies arise in its sphere, generated by an internal dialogue, in the course of which the former cultural achievements that have gone into the shadow are also actualized.

The apperance of philosophy in a separate ethnic group does not occur immediately. For this, an appropriate time must come when social relations become more complex and differentiate, there is a need for creative, integration intentions. It penetrates in all the other "historical aspects of the national spirit; it is in close connection with them and forms their basis" [9, p. 110]. Hegel defines philosophy as one of the diverse aspects of folk culture, constituting the highest color, the concept of the whole image of the spirit, the spirit of the time as the spirit thinking itself, and "the diverse whole is reflected in it, as in a simple focus, as in its self-knowing concept" [9, with. 111].

Of course, the national philosophical tradition has a successive character, it connects the past with the present, interprets the intellectual activity of individual personalities, creativity, the knowledge of which is a condition for interested discussion of philosophical problems. Meanwhile, the national philosophy has its specific features. Thus, English philosophy is considered empirical-analytical, French one is rationalistic, German speculativeidealistic. Between them existed and continue to exist significant differences, contradictory relationships.

On this occasion, M. Mamardashvili noted that philosophers belonging to various philosophical schools of the twentieth century were mocking and scornful; the neopositivists were the most scornful because they considered themselves "very scientific", attached to the esteemed establishment of science. Such a philosopher as Heidegger did not cause anything but contemptuous tricks and smiles from, for example, Rudolf Carnap (one of the basic logical positivists), but on the contrary (the feeling was mutual) [10, $p$. 496]. Some neopositivists exposed psychoanalysis as quackery and the magic of the twentieth century, and thus this philosophical trend was taken out of the brackets of the neopositivist-scientistic interpretation of philosophy.

M. Mamardashvili described the non-positivist trend as Anglo-Saxon philosophy, which was mainly popular in countries with English and German languages, as well as in the USA, where it is widely spread in American universities. During the Anschluss, 13 members of the "Vienna Circle" moved from Austria to the USA, which had a great importance on the development of philosophy in this country, especially its direction sich as a logical analysis.

The ideas of this philosophical association to the mid-1930s. gained wide popularity in Europe and the USA. The analytical direction of the philosophy of science developed by 
him included the following science-oriented ideas: 1) philosophy should have a scientific character or a general empirical orientation and positivism, it should be guided by the goals and methods of empirical science; 2 ) it is necessary to combat philosophical speculations, to have an anti-metaphysical orientation; 3) a philosophical tool of analysis should be a commitment to the idea of logic; 4) the implementation of the unity of scientific knowledge on the basis of the principle of physicalism; 5) philosophical studies should have a collective, international character [3].

The role of B. Russell in the development of neopositivism in England is significant, Austrian-German philosophers rushed to him from continental Europe, among them there was the original thinker, engineer by education, Ludwig Wittgenstein, who wrote a small, meaningful essay, Logical and Philosophical Treatise, set out in the basis of seven aphoristic theses [8, p. 21], deployed in a holistic system, interpreting the relationship of language and the world. This manifesto of the analytical philosophy of science is the only work published during his lifetime. Contemporaries, believing that there is nothing of the kind in the European philosophical tradition, give such an assessment to L. Wittgenstein's treatise: reflections, reflections and reflections again, quite comparable with meditation, which Eastern philosophy attributes to everyone who wants to find wisdom, and the published result of these reflections is with the achievement of the "state of one thought" (dhyana) [10, p. 8].

Reflecting on the national forms of philosophy, it is important to dwell on Russian philosophy as a special sphere of the spiritual life of society. Of course, its development was influenced by the intellectual thought of the West. But at the same time it has its own regional, national specificity. It pays close attention to social issues. Russian philosophy was focused on improving the life of the people, thinking about its better future, looking for ways to organize a perfect life, speaking out against reality with its untruth and ugliness. Russian philosophy can be described as a folk worshiper: after all, the Russian intelligentsia has always considered itself indebted to the people, calling for their release from social and moral borders.

The range of meaningful ideas of Russian philosophy is wide, ranging from calls for a popular revolution and a socially just reorganization of society to the achievement of the utopian positions of universal brotherhood and Christian love. The Russian philosophy is emotionally rational, the subject of its analysis is deep existential, life-conscious problems; she is mystical irrational. For a number of Russian thinkers, philosophical creativity is primarily moral teachings, Christian humanism, which is associated with the ideas of V. Solovyov, L. Tolstoy, V. Rozanov, K. Leontiev and others.

At the same time, the theme of the old and new Russia, Russia and the West sounds emotionally and hysterically in Russian philosophy. And in this regard, I think it is appropriate to bring the lines of the poet-thinker A. Blok from his poem "Russia":

$$
\begin{gathered}
\text { «Kakomu hochesh charodeyu } \\
\text { Otdaj razbojnuyu krasu, } \\
\text { Puskaj zamanit i obmanet, - } \\
\text { Ne propadesh, ne sginesh ty, } \\
\text { I lish zabota zatumanit } \\
\text { Tvoi prekrasnye cherty». }
\end{gathered}
$$

Of course, from the point of view of modern times, we Russians, Caucasians do not like this poetic metaphor: 'to give a beauty to a sorcerer to lure and deceive'. Deception of modern fraudsters, cheats, brokers, dealers almost led to the death of the country, it almost vanished. And today people, the intelligentsia has become much more concerned. 
As N. Berdyaev notes, in the Russian culture of the nineteenth century, the religious theme was of crucial importance, and "Russian religious philosophy especially insisted that philosophical knowledge is knowledge in a holistic spirit, in which mind combines with will and feeling and in which there is no rationalistic dismemberment "[4, p. 197].

Russian consciousness of the nineteenth century, of course, anti-Western, directed against the Logos, anti-rationalistic, but cosmo-mystical. It is not generally reflected in the categories of Christian, but Christian motifs remain [4, p. 276].

Twentieth century generated national socio-philosophical systems based on the ideas of education, freedom, independence, scientific and technological development, and social progress. Numerous national states was found in the Middle East, Africa, Central and South Asia, and Latin America, existence of which required a philosophical understanding of their past, present, and future. Here in ideological terms, the ideology of capitalism and socialism clashed, the peoples and their leaders chose between them and the world was divided into two camps, balancing each other. The fall of the socialist system radically changed the socio-philosophical world outlook of the peoples, national intelligentsia, and thinkers.

Russian philosophy with all its zigzags, contradictions has come a significant way in its development. Its ideas were especially bourgeois-democratic, proletarian socialist penetrated into the cultures of the peoples of the USSR, where they were actualized taking into account national-spiritual characteristics, received a new life in national cultures.

In the years of the USSR a multivolume edition was published, which reflected the philosophy of the peoples of the country. It reflected the historical-philosophical, sociopolitical, spiritual and religious thought of the peoples of Central Asia, Georgia, Armenia, Azerbaijan, the North Caucasus, the Baltic States. Unfortunately, today in our country there are still no such generalizing works, although social, philosophical, scientific thought in various regions of Russia and the republics, in spite of social and spiritual crises, continues to pulsate, achieving certain results. In Moscow, Rostov-on-Don, St. Petersburg, Tatarstan, Dagestan, Bashkortostan, and the Chechen Republic, philosophical congresses, congresses, international conferences on fundamental problems of philosophy are regularly held, at which recognized scientists, philosophers not only from the capital, but also from Russian periphery.

In the course of research on the national cultures of the North Caucasian peoples, three important trends emerged that require concretization and further development: an analysis of the characteristics of folk culture manifested through the national language, customs, traditions, ethno-psychological characteristics; consideration of national cultures in their relations and contacts with Russian and European cultures; studying the influence of religious, Islamic (Sufi) culture on traditional ethno-national cultures [1, p. 19].

In Soviet times, the development of philosophical thought in the North Caucasus was associated with the training of national personnel at the Philosophy Department of the Moscow State University, the Institute of Philosophy of the Russian Academy of Sciences, the Philosophy Department of the Leningrad State University (St. Petersburg State University), the Department of Philosophy of the Moscow State Pedagogical Institute. IN AND. Lenin, Faculty of Philosophy RSU (now SFU). To a large extent, these trends persisted, although with some adjustments.

In the development of philosophy and social thought in the modern Chechen Republic, prominent representatives of the Rostov school of philosophy and politics have played and play a significant positive role: Yu.A. Zhdanov, E.V. Davidovich, G.V. Drach, E.E. Nesmeyanov, A.M. Starostin, A.N. Ponedelkov, M.M. Taysumov, V.V. Chernous and others 
In the context of thinking about the development of national philosophy, it is necessary to dwell on the original ideas of M.I. Bilalov expressed in such studies as "Gnoseological ideas in the structure of religious consciousness", "Civilizational metamorphoses of cognitive culture", "Comprehensibility of truth" $[5,6,7]$. The originality of his philosophical reflections lies in the desire to accumulate the philosophical ideas of modernity, among which there is the philosophy of postmodernism, which is compared with the cognitive historical and philosophical tradition, Russian intellectual culture, Eastern and Muslim philosophy. This synthetic author's concept is determined by the concern over the possible deconstruction of national minorities with their cultures and identities in the context of globalization.

The scientist is disturbed by the approach of the time of fakes, disguise, blurring of reality, distortion of truth [6, p. 348], which is typical of the information society, postmodern culture. In his intellectual work "The Comprehensibility of Truth" M.I. Bilalov, recognizing that the crisis of philosophy is a temporary phenomenon, considers it to be eternally alive, will remain so, as long as culture is alive, truth is alive, humanity is alive [5, p. 368]. In fact, these are the keywords of his expanded anthem of philosophy.

Of course, the development of national cultures among different peoples takes place within the framework of different spatial and temporal coordinates and cultural systems, thus forming an intellectual philosophical vision of the world, society, and man. This suggests the emergence of various forms of national philosophies: Indian, Chinese, Greek, German, French, English, Russian, American, Georgian, and so on. M.I. Analyzing them, Bilalov examines the concept of the mind, which is inherent in different nations - Jews, Greeks, French, English, Russian, while revealing special and common features. In the context of the author's vision, the philosophical culture of the peoples of the North Caucasus, including the peoples of Dagestan, is considered, emphasizing its essential mystical, irrational component, in the absence of a pronounced rational component [5].

In the Muslim regions of Russia, the problems associated with the revival of Islam, its impact on ethno-national cultures, the processes of religious radicalization, the emergence of extremism and terrorism were actualized [2, p. 28-34]. Certainly, this spiritual situation requires a deep analysis, identification of ideological foundations, external and internal ideological factors. However, it seems to us, in domestic studies there is a one-sided trend, a superficial analysis that takes little account of the social factors that determine asocial processes that increase the religious and political situation in society.

Meanwhile, this important formulation of the problem, because it is necessary to thoroughly disclose the characteristics of local-regional, national cultures, which, it seemed, are formed in isolation, far from civilization, scientific and technological revolution. But, nevertheless, while preserving their ethnocultural values, they absorb the achievements of modernity, master them, sometimes enriching, developing archaic, national cultures.

This is characteristic of all the peoples of the North Caucasus, who have achieved significant results in intellectual development during their historical development, overcoming sociocultural and technological backwardness.

Modern postindustrial, informational improvement of various Western and Eastern societies, is based on new scientific, technical, biotechnological, informational achievements, which does not preclude the preservation of cultural and philosophical traditions of peoples. But they are naturally not immediately revised, gradually, and they are interpreted in a new way, taking into account the modern social, economic, civilizational context. And this situation affects the cultures of the peoples of the North Caucasus, an adequate philosophical reflection of which is still to be implemented. 


\section{Лumepamypa}

1. Акаев В.Х. Исследование общественной и религиозно-философрской мысли народов Северного Кавказа: достижения, трудности и перспективы // Материалы Всероссийской научно-теоретической конференции «Изучение культурного наследия народов России - актуальная задача». 8 декабря 2006 г. Махачкала: ИД «Эпоха», 2007.

2. Акаев В.X. Мобилизация этнокультурного ресурса в процесс противодействия проявлениям религиозного экстремизма // Мобилизация этнокультурного ресурса как важнейший фактор противодействия экстремизму и терроризму: Сборник материалов Международной научно-практической конференции (Грозный, 24-26 ноября 2017 г.). Грозный: Издательско-полиграфический комплекс «Грозненский рабочий», 2018.

3. Аналитическая фрилософия / Под ред. М.В. Лебедева и А.3. Чернова, М.: Изд-во РУДН, 2006 // https://vikent.ru/enc/3856/: https://vikent.ru/enc/3856/ (дата обращения 20.07.2018)

4. Бердяев Н. Русская идея. СПб.: Издательский Дом Азбука-классика, 2008.

5. Билалов М.И. Гносеологические идеи в структуре религиозного сознания. М.: Academia, 2003.

6. Билалов М.И. Постижимость истины: уловимость, объяснимость, выразимость. Махачкала, 2017.

7. Билалов М.И. Цивилизационные метаморфозы познавательной культуры. М.: Academia, 2008.

8. Витгенштейн Л. Логико-фрилософский трактат. М.: АСТ: Астрель, 2010.

9. Гегель Г.В.Ф. Лекции по истории философиии. Книга первая. СПб.: Наука, 1998.

10.Королев Кирилл. Книга потерянного поколения, или алмазная сутра логики // Витгенштейн Л. Логико-философский трактат. М.: АСТ: Астрель, 2010.

11. Мамардашвили Мераб. Очерк современной европейской философии. СПб: Азбука, Азбука-Аттикус, 2014.

12. Meskhi B.Ch., Astvatsaturov A.E. Human factor in solving engineering problems of safety // Научный альманах стран Причерноморья. 2015. N 1. http://sciencealmanac.ru

\section{References}

1. Akaev V.H. Issledovanie obshchestvennoj i religiozno-filosofskoj mysli narodov Severnogo Kavkaza: dostizheniya, trudnosti i perspektivy // Materialy Vserossijskoj nauchno-teoreticheskoj konferencii «Izuchenie kulturnogo naslediya narodov Rossii aktualnaya zadacha». 8 dekabrya 2006. Mahachkala: ID «EHpoha», 2007. (in Russian).

2. Akaev V.H. Mobilizaciya ehtnokul'turnogo resursa $v$ process protivodejstviya proyavleniyam religioznogo ehkstremizma // Mobilizaciya ehtnokulturnogo resursa kak vazhnejshij faktor protivodejstviya ehkstremizmu i terrorizmu: Sbornik materialov Mezhdunarodnoj nauchno-prakticheskoj konferencii (Groznyj, 24-26 noyabrya 2017). Groznyj: Izdatelsko-poligraficheskij kompleks «Groznenskij rabochij», 2018. (in Russian).

3. Analiticheskaya filosofiya / Pod red. M.V. Lebedeva i A.Z. CHernova, M.: Izd-vo RUDN, 2006// https://vikent.ru/enc/3856/: https://vikent.ru/enc/3856/ (data obrashcheniya 20.07.2018) (in Russian). 
4. Berdyaev N. Russkaya ideya. SPb.: Izdatelskij Dom «Azbuka-klassika», 2008. (in Russian).

5. Bilalov M.I. Gnoseologicheskie idei v strukture religioznogo soznaniya. M.: Academia, 2003. (in Russian).

6. Bilalov M.I. Postizhimost istiny: ulovimost, obyasnimost, vyrazimost. Mahachkala, 2017. (in Russian).

7. Bilalov M.I. Civilizacionnye metamorfozy poznavatel'noj kul'tury. M.: Academia, 2008. (in Russian).

8. Vitgenshtejn L. Logiko-filosofskij traktat. M.: AST: Astrel, 2010. (in Russian).

9. Gegel G.V.F. Lekcii po istorii filosofii. Kniga pervaya. SPb.: Nauka, 1998. (in Russian).

10. Korolev Kirill. Kniga poteryannogo pokoleniya, ili almaznaya sutra logiki // Vitgenshtejn L. Logiko-filosofskij traktat. M.: AST: Astrel', 2010. (in Russian).

11. Mamardashvili Merab. Ocherk sovremennoj evropejskoj filosofii. SPb: Azbuka, Azbuka-Attikus, 2014. (in Russian).

12. Meskhi B.Ch., Astvatsaturov A.E. Human factor in solving engineering problems of safety. Science almanac of Black Sea region countries. 2015. No. 1. Available at: http://science-almanac.ru 